\title{
KEDUDUKAN AGUNAN DALAM AKAD PEMBIAYAAN MUDHARABAH PADA BANK SYARIAH
}

\author{
Vendra Irawan \\ Universitas Muhammadiyah Yogyakarta, vendrairhawan@ymail.com
}

\author{
Diterima: 22 Agustus $2019 \quad$ Direvisi:13 November $2019 \quad$ Diterbitkan: 25 Desember 2019
}

\begin{abstract}
The purpose of this research is to examine the position of collateral in the mudharabah financing contract in Islamic banking. The type of research used is normative research with a statute approach and a conceptual approach. The sources of legal material in this study are from primary legal material and secondary legal material. The results of the analysis of this study are that the collateral position in the mudharabah contract in Islamic banking is different from the position of collateral in conventional banking, collateral in conventional banking functions as guarantor of the debts that occur between creditors and debtors. While the function of collateral in the mudharabah agreement on Islamic banking is to ensure the implementation of the mudharabah agreement in accordance with the agreement made in the beginning of the agreement between capital owners and business manager. So, the purpose of collateral in mudharabah contract is to avoid bad moral of business manager and not to return the investment value if there is a loss due to business risk factors.
\end{abstract} Keywords: Position, Collateral, Mudharabah, Islamic Bank.

\begin{abstract}
Abstrak
Penelitian ini bertujuan untuk mengkaji kedudukan agunan dalam akad pembiayaan mudharabah pada perbankan syariah. Jenis penelitian yang digunakan adalah penelitian normatif dengan pendekatan perundang-undangan dan pendekatan konseptual. Sumber bahan bukum dalam penelitian ini adalab dari bahan bukum primer dan bahan bukum sekunder. Hasil analisis dari penelitian ini adalah kedudukan agunan pada akad mudharabah di perbankan syariah berbeda dengan kedudukan agunan pada perbankan konvensional, agunan pada perbankan konvensional berfungsi sebagai penjamin atas utang-piutang yang terjadi antara kreditur dengan debitur. Sedangkan fungsi agunan dalam akad mudharabah pada perbankan syariah adalah untuk menjamin terlaksananya akad mudharabah sesuai dengan kesepakatan yang telah dibuat diawal perjanjian antara shabib al-maal dengan mudharib. Jadi, tujuan agunan dalam akad mudharabah adalah untuk mengbindari moral jelek mudharib dan bukan untuk mengembalikan nilai investasi jika terjadi kerugian karena faktor risiko bisnis.
\end{abstract}

Kata Kunci: Kedudukan, Agunan, Mudharabah, Bank Syariah.

\section{PENDAHULUAN}

Sistem ekonomi Islam mulai marak dikembangkan di negara-negara basis Islam kuat saat ini khususnya disektor perbankan, bahkan bank-bank syariah pun juga berkembang di negara-negara barat atau non Islam, seperti di Denmark, Luksemburg, Switzerland dan The United Kingdom. ${ }^{1}$ Sistem ekonomi Islam ini dinilai cocok untuk mewujudkan kemaslahatan dan kesejahteraan

${ }^{1}$ N S Imaniyati dan P.T.C.A. BAKTI, AspekAspek Hukum BMT (Baitul Maal wat Tamwil) (Citra Aditya Bakti, 2010). 44. bersama di masyarakat karena berorientasi pada pembangunan yang berkeadilan di antara seluruh pelaku dan komponen di dalam masyarakat.

Pada dasarnya sistem ekonomi Islam itu dimulai sejak kedatangan agama Islam itu sendiri yang dibawa oleh Nabi Muhammad SAW dari Allah SWT, utamanya sejak agama Islam didukung oleh sebuah negara di kota Madinah. Hal pertama yang beliau lakukan setelah membangun mesjid sebagai tempat ibadah, pendidikan dan pemerintahan ialah membangun sebuah pasar untuk untuk kaum 
muslimin dengan tujuan melepaskan mereka dari monopoli kaum Yahudi dan penguasaan mereka terhadap ekonomi kota Madinah. Kemudian Rasulullah SAW mengatur perdagangan sesuai peraturan-peraturan baru, seperti kebebasan dagang, keadilan, pelarangan segala bentuk tipu daya, praktik monopoli, ketepatan timbangan dan segala keburukan sistem perdagangan yang ditumbuhkan oleh kaum Yahudi dimana hal itu serupa dengan sistem ekonomi kapitalis modern. ${ }^{2}$

Oleh karena itu, sarana untuk mencegah timbulnya fenomena ketidakadilan yang paling menonjol adalah pelarangan riba. Hakikat pelarangan riba dalam Islam adalah suatu penolakan terhadap timbulnya risiko finansial tambahan yang ditetapkan dalam transaksi uang atau modal maupun jual beli yang dibebankan kepada satu pihak saja, sedangkan pihak yang lainnya dijamin keuntungannya. Syekh Yusuf Qardhawi menyatakan bahwa dasar pengharaman riba adalah melanggar perbuatan zalim bagi masing-masing dari kedua belah pihak, maka tidak boleh menzalimi dan tidak boleh dizalimi. ${ }^{3}$

Salah satu tonggak perkembangan perbankan Islam adalah didirikannya Islamic Development Bank (IDB) pada tahun 1975 yang berpusat di Jeddah. Bank pembangunan yang menyerupai Bank Dunia (The World Bank) dan Bank Pembangunan Asia (Asian Development Bank) ini dibentuk oleh Organisasi Konferensi Islam (OKI) yang anggotaanggotanya adalah negara-negara Islam, termasuk Indonesia. Berdirinya IDB ini kemudian memicu berdirinya bank-bank Islam di seluruh dunia, seperti di kawasan Eropa, Timur Tengah dan Asia Tenggara. Sedangkan di Indonesia, bank Islam pertama baru bisa

\footnotetext{
2 Muhamad, Pengantar Bisnis Syariah (Yogyakarta: UPP STIM YKPN, 2019). 16.

3 Muhamad, Lembaga-Lembaga Keuangan Umat Kontemporer (Yogyakarta: UII Press Yogyakarta, 2000). 28.
}

didirikan pada tahun 1991, yaitu dengan nama Bank Muamalat Indonesia (BMI). ${ }^{4}$

Keberadaan bank syariah sangat mendukung pemenuhan kebutuhan manusia di bidang ekonomi, namun kebutuhan manusia di bidang ekonomi pun harus diiringi dengan kepastian hukum yang adil agar tercipta efektifitas dan efisiensi. Oleh karena itu tampak jelas adanya hubungan yang erat antara hukum dan ekonomi. Sistem hukum sebagai perwujudan dari sistem ekonomi. Demikian pula sebaliknya, sistem ekonomi suatu bangsa akan tercermin dalam sistem hukumnya. ${ }^{5}$

Sejak diberlakukannya UndangUndang Nomor 10 Tahun 1998 tentang Perbankan yang merupakan perubahan atas Undang-Undang Nomor 7 Tahun 1992 tentang Perbankan, industri perbankan di Indonesia terbagi menjadi bank yang beroperasi berdasarkan bunga (bank konvensional) dan bank yang beroperasi berdasarkan bagi hasil atau syariah Islam (bank syariah).

Bank syariah atau biasa disebut dengan bank tanpa bunga yang menjalankan kegiatan usahanya berdasarkan Syariah Islam dilaksanakan dengan menggunakan instrumen bagi hasil. ${ }^{6}$ Sebab bank syariah secara eksplisit melarang penerapan tingkat bunga pada semua transaksi keuangannya. Oleh karena itu, produk-produk yang ditawarkan oleh bank syariah haruslah sejalan dengan konsep syariah.

Salah satu diantara produk-produk atau prinsip bagi hasil dalam perbankan syariah yang banyak dipakai di bank syariah dalam hal

4 Adiwarman A. Karim, Bank Islam Analisis Fiqih dan Keuangan (Jakarta: PT RajaGrafindo Persada, 2008). XX.

5 Dewi Nurul Musjtari, "Rekonstruksi Lembaga Penyelesaian Sengketa Akad Pembiayaan Dengan Jaminan Hak Tanggungan Pasca Putusan Mahkamah Konstitusi Nomor 93/PUU-X/2012," Jurnal Media Hukum, Vol. 23, No. 1 (Juni, 2016). 63.

6 Muhammad, Konstruksi Mudharabah dalam Bisnis Syariab: Mudharabah dalam Wacana Fiqih dan Praktik Ekonomi Modern (Yogyakarta: BPFE Yogyakarta, 2005). 2. 
financing (penyaluran dana atau pembiayaan) kepada masyarakat ialah pembiayaan bagi hasil dengan akad mudharabah.

Mudharabah merupakan akad kerjasama usaha antara dua pihak di mana pihak pertama (shabib al-maal) menyediakan seluruh modalnya $(100 \%)$, sedangkan pihak lainnya sebagai pengelola (mudharib). ${ }^{7}$ Keuntungan usaha dalam akad mudharabah dibagi menurut kesepakatan yang dituangkan dalam kontrak, sedangkan apabila terjadi kerugian ditanggung oleh pemilik modal selama kerugian tidak dikarenakan kesengajaan dan kelalaian pengelola, jika kerugian itu disebabkan kesalahan atau kelalaian pengelola, maka pengelola harus bertanggungjawab atas kerugian usaha tersebut ${ }^{8}$

$$
\text { Fatwa Dewan Syariah Nasional }
$$
Nomor 07/DSN/MUI/IV/2000 tentang Pembiayaan Mudharabah pada bagian Ketiga Angka 3 dijelaskan "Pada dasarnya, dalam mudharabah tidak ada ganti rugi, karena pada dasarnya akad ini bersifat amanah (yad alamanab), kecuali akibat dari kesalahan disengaja, kelalaian, atau pelanggaran kesepakatan". Akad mudharabah ini sangat mengedepankan kepercayaan (amanah) diantara masing-masing pihak dengan menjunjung keadilan serta menuntut kejujuran yang tinggi demi menjaga kepentingan bersama. Walaupun akad mudharabah ini bersifat amanah, akan tetapi hampir semua lembaga perbankan syariah di Indonesia selalu mewajibkan kepada mudharib untuk menyertakan agunan ketika melakukan akad pembiayaan mudharabah tersebut.

Berdasarkan permasalahan yang telah dipaparkan diatas, maka peneliti tertarik untuk mengkaji lebih mendalam tentang Kedudukan Agunan dalam Akad Pembiayaan Mudharabah

\footnotetext{
7 Muhamad, Manajemen Keuangan Syari'ab (Yogyakarta: UPP STIM YKPN, 2014). 239.

${ }^{8}$ Heri Sudarsono, Bank dan Lembaga Keuangan Syariah Deskripsi dan Ilustrasi (Yogyakarta: Ekonosia, 2004). 70.
}

pada Bank Syariah. Adapaun tujuan penelitian ini adalah untuk mengkaji dan menjelaskan kedudukan agunan dalam akad pembiayaan mudharabah pada perbankan syariah.

\section{METODE PENELITIAN}

Jenis penelitian yang digunakan dalam penelitian ini adalah penelitian yuridis normatif, yaitu suatu metode penelitian hukum yang dilakukan dengan meneliti bahan pustaka atau data sekunder. ${ }^{9}$ Adapun tujuan dilakukannya penelitian ini adalah untuk mengidentifikasi konsep, prinsip-prinsip, aturan hukum dan asas-asas yang digunakan untuk menganalisis kedudukan agunan dalam akad pembiayaan mudharabah pada perbankan syariah.

Pendekatan penelitian yang digunakan dalam penelitian ini adalah pendekatan Perundang - Undangan (statute approach) dan pendekatan Konseptual (conceptual approach). Pendekatan perundang-undangan (statue approach) dilakukan dengan menelaah berbagai aturan hukum yang berkaitan dengan konsep pembiayaan mudharabah pada perbankan syariah. Sedangkan pendekatan konseptual (conceptual approach) dilakukan untuk memahami konsep-konsep yang berhubungan dengan kedudukan agunan dalam akad pembiayaan mudharabah pada perbankan syariah.

Sumber bahan hukum dalam penelitian ini berasal dari bahan hukum primer dan bahan hukum sekunder. Bahan hukum primer diperoleh dari Undang-Undang Nomor 21 Tahun 2008 tentang Perbankan Syariah, Undang-Undang Nomor 10 Tahun 1998 tentang Perbankan perubahan atas UndangUndang Nomor 7 Tahun 1992, UndangUndang Nomor 3 Tahun 2004 tentang Bank Indonesia, Fatwa Dewan Syariah Nasional Nomor 07/DSN/MUI/IV/2000 tentang Pembiayaan Mudharabah, Peraturan Bank

${ }^{9}$ Soejono Soekanto dan Sri Mamudji, Penelitian Hukum Normatif: Suatu Tinjauan Singkat (Jakarta: Rajawali Pers, 2001). 13-14. 
Indonesia Nomor: 9/19/PBI/2007 tentang Pelaksanaan Prinsip Syariah dalam Kegiatan Penghimpunan Dana dan Penyaluran Dana Serta Pelayanan Jasa Bank Syariah, Buku Kedua Kompilasi Hukum Ekonomi Syariah (KHES) dan peraturan lainnya yang berkaitan dengan penelitian ini. Sedangkan bahan hukum sekunder bertujuan membantu menganalisis dan memberikan pemahaman terkait dengan penelitian yang dilakukan, antara lain: Al-Qur'an, As-Sunnah, Ijma', buku-buku, hasil penelitian, jurnal ilmiah, artikel ilmiah, dan makalah hasil seminar yang berkaitan dengan konsep pembiayaan mudharabah pada perbankan syariah.

Metode pengumpulan data yang digunakan dalam penelitian ini adalah dengan melakukan studi kepustakaan, yaitu dengan mempelajari, memahami dan mengkaji tafsir Al-Qur'an, Hadits, Ijma', peraturan perundang-undangan, buku-buku, jurnal ilmiah, serta tulisan para pakar atau cendekiawan yang ada hubungannya dengan tema penelitian ini.

Data dianalisis menggunakan tiga metode dalam analisis data kualitatif, antara lain: ${ }^{10}$ Pertama, Reduksi data, yaitu membuat rangkuman, pengodean, membuat tema-tema, membuat gugus-gugus, membuat pemisahpemisah, menulis memo-memo. Kedua, Model data, dilakukan dengan cara menampilkan data, membuat hubungan antar fenomena untuk memaknai apa yang sebenarnya terjadi dan apa yang perlu ditindaklanjuti untuk mencapai tujuan penelitian. Ketiga, Penarikan/verifikasi kesimpulan, yaitu peneliti memverifikasi datadata yang didapatkan ketika melakukan studi kepustakaan, lalu data-data yang didapatkan tersebut diproses dan dianalisis, serta membuang data-data yang tidak diperlukan.

${ }^{10}$ Emzir, Metodologi Penelitian Kualitatif: Analisis Data (Jakarta: Penerbit Rajawali Pers, 2010). 129-135.

\section{TINJAUAN \\ UMUM}

MUDHARABAH

Al-Mudharabah, berasal dari kata dharb, artinya memukul atau berjalan. Maksud dari memukul atau berjalan disini adalah proses seseorang memukulkan kakinya dalam menjalankan usaha atau melakukan perjalanan untuk berdagang. ${ }^{11}$

Istilah Mudharabah dengan pengertian bepergian untuk berdagang, diambil dari bahasa yang dipakai oleh bangsa Irak. Sedangkan oleh ahli (penduduk) Hijaz menggunakan istilah qiradh, yang diambil dari kata qardh yang artinya: memotong. Dinamakan demikian, karena pemilik modal memotong sebagian dari hartanya untuk diperdagangkan oleh amil dan memotong sebagian dari keuntungannya. ${ }^{12}$

Syekh Sayid Sabiq memberikan definisi mudharabah, yaitu suatu akad antara dua pihak di mana salah satu pihak memeberikan uang (modal) kepada pihak lain untuk diperdagangkan dengan ketentuan bahwa keuntungan dibagi di antara mereka berdua sesuai dengan kesepakatan mereka. ${ }^{13}$

Sedangkan Syekh Wahbah Zuhaili mendefinisikan, mudharabah adalah akad penyerahan modal oleh si pemilik kepada pengelola untuk diperdagangkan dan keuntungan dimiliki bersama antara keduanya sesuai dengan persyaratan yang mereka buat. ${ }^{14}$

Kemudian dalam beberapa referensi lainnya juga dijelaskan mengenai definisi dari akad mudharabah, bahwa mudharabah adalah bentuk akad antara dua pihak dimana satu pihak berperan sebagai pemilik modal (shabib al-maal) dan mempercayakan sejumlah modalnya untuk dikelola oleh pihak kedua, yakni si pelaksana usaha (mudharib) dengan

${ }^{11}$ Sayid Sabiq, Fiqh As-Sunnah, Juz 3 (Beirut: Dar Al-Fikr, 1981). 212.

12 Ahmad Wardi Muslich, Figh Muamalat (Jakarta: Amzah, 2013). 366.

${ }^{13}$ Sayid Sabiq, Figh Sunnah, 212.

14 Wahbah Zuhaili, Al-Fiqbu Al-Islami waAdilatubu, Juz 4 (Damaskus: Dar Al-Fikr, 1989). 836. 
tujuan untuk mendapatkan untung (Adiwarman A. Karim, 2004: 204-205). ${ }^{15}$ Atau dengan kata lain dikatakan bahwa akad mudharabah adalah persetujuan kongsi antara harta dari salah satu pihak dengan kerja di pihak lain (M. Anwar Ibrahim, 2002).

Jadi, mudharabah merupakan kontrak kerjasama antara dua pihak dimana satu pihak sebagai pemilik modal (shabib al-maal) mempercayakan uangnya kepada pihak kedua sebagai pengelola (mudharib) untuk tujuan menjalankan suatu usaha dagang dan keuntungannya dibagi menurut kesepakatan mereka yang dituangkan dalam kontrak, yang mana mudharib menyumbangkan tenaga, waktunya dan mengelola perkongsian mereka tersebut berdasarkan proporsi yang telah disepakati sebelumnya.

Kerugian dan risiko yang muncul dalam akad mudharabah akan ditanggung sendiri oleh si investor atau pemilik modal (shabib al-maal), kecuali kerugian tersebut disebabkan oleh kesalahan yang disengaja, kelalaian dan pelanggaran kesepakatan oleh mudharib. Seandainya kerugian itu diakibatkan karena kecurangan atau kelalaian si pengelola, maka si pengelola harus bertanggung jawab atas kerugian tersebut. Salah satu ciri utama dari kontrak ini adalah bahwa keuntungan, jika ada akan dibagi antara investor/pemilik modal dan pengelola (mudharib) sesuai nisbah yang disepakati diawal kontrak. ${ }^{16}$

Mudharabah telah dikenal oleh ummat Muslim sejak zaman Nabi SAW, bahkan telah dipraktikkan oleh bangsa Arab sebelum turunnya Islam. Ketika Nabi Muhammad SAW berprofesi sebagai pedagang, beliau melakukan akad mudharabah dengan Khadijah. ${ }^{17}$

15 Danang Wahyu Muhammad, "Kajian tentang Pembiayaan Mudharabah pada Bank Syariah," Jurnal Media Hukum (Desember, 2011). 232.

16 Abdullah Saeed, Menyoal Bank Syariab: Kritik Atas Interpretasi Bunga Bank Kaum Neo-Revivalis (Jakarta: Paramadina, 2004). 77.

17 Adiwarman, Bank Islam. 180.
Mengenai praktik mudharabah antara Khadijah dengan Nabi Muhammad SAW, saat itu Khadijah mempercayakan barang dagangannya untuk dijual ke Nabi Muhammad SAW ke luar negeri. Pada kasus ini Khadijah berperan sebagai pemilik modal (shabib al-maal) sedangkan Nabi Muhammad SAW berperan sebagai pelaksana usaha (mudharib). ${ }^{18}$

Ibnu Rusyd dari Mazhab Maliki menyatakan bahwa dalam Islam akad mudharabah dibolehkan, karena bertujuan untuk saling membantu antara shabib al-maal (investor) dengan pengelola dagang (mudharib). Kebolehan akad mudharabah merupakan suatu kelonggaran yang khusus. ${ }^{19}$ Meskipun mudharabah tidak secara langsung disebutkan dalam al-Qur'an maupun Sunnah, ia adalah sebuah kebiasaan yang diakui dan dipraktikkan oleh ummat Islam sejak periode awal era Islam.

Secara garis besar ada dua jenis akad mudharabah: $:^{20}$

1. Mudharabah Muthlaqah, merupakan mudharabah yang sifatnya mutlak dimana shabib al-maal tidak menetapkan restriksi atau syarat-syarat tertentu kepada mudharib;

2. Mudharabah Muqayyadah, yaitu pemilik modal (shabib al-maal) membatasi atau memberi syarat kepada mudharib dalam pengelolaan modalnya, misalnya hanya untuk melakukan mudharabah bidang tertentu, cara, waktu, dan tempat tertentu saja.

Menurut Hanafiah, rukun akad mudharabah adalah ijab dan qabul, dengan menggunakan lafal yang menunjukkan kepada arti mudharabah. Lafal yang digunakan untuk ijab ialah lafal mudharabah, muqaradhah dan mu'amalah, serta lafal-lafal lain yang artinya sama dengan lafal-lafal tersebut. Seperti

18 Nafan, Pembiayaan Musyarakah dan Mudharabah (Yogyakarta: Graha Ilmu, 2014). 114. Al-Fkir). 78.

${ }^{19}$ Ibnu Rusyd, Bidayah al-Mujathid (Mesir: Dar

${ }^{20}$ Syafi'i Antonio, Bank Syariah Wacana Ulama dan Cendikiawan (Jakarta: Tazkia Institute, 1999). 73. 
contoh, pemilik modal mengatakan: “Ambillah modal ini dengan mudharabah, dengan ketentuan keuntungan yang diperoleh dibagi di antara kita berdua dengan nisbah setengah, seperempat atau sepertiga." Adapun lafal qabul yang digunakan oleh pengelola (mudharib) adalah lafal: saya ambil atau saya terima atau saya setuju dan semacamnya. ${ }^{21}$ Berdasarkan pendapat ini apabila ijab dan qabul telah terpenuhi, maka akad mudharabah tersebut telah sah.

Sedangkan menurut Syafi'iyah, bahwa rukun mudharabah ada 5 (lima), antara lain::22

1. Modal;

2. Tenaga (pekerjaan);

3. Keuntungan;

4. Shigat,

5. 'Aqidain.

Adapun rukun akad mudharabah menurut Jumhur Ulama adalah sebagai berikut: ${ }^{23}$

1. Dua orang yang melakukan akad (alaqidani);

2. Ma'qud 'alaib (yaitu modal, tenaga dan keuntungan);

3. Sighat (ijab dan qabul).

Akad mudharabah dinyatakan berakhir atau batal dalam hal-hal sebagai berikut: ${ }^{24}$

1. Masing-masing pihak menyatakan batal, atau pekerja dilarang untuk bertindak hukum terhadap modal yang diberikan, atau pemilik modal menarik modalnya;

2. Salah seorang yang berakad meninggal dunia;

3. Salah seorang yang berakad gila, karena orang gila tidak cakap lagi bertindak hukum;

4. Pemilik modal murtad (keluar dari agama Islam), menurut Imam Abu Hanifah akad mudharabah batal. Akan tetapi, apabila mudharib yang murtad, maka akad

21 'Alaudin Al-Kasani, Badaai' Ash-Shanai' fi Tartib Asy-Syarai', Juz 6 (Beirut: Dar Al-Fikr, 1996). 121.

22 Zuhaili, Al-Fiqhu Al-Islami...., 839.

${ }^{23}$ Nafan, Pembiayaan..., 117.

${ }^{24}$ Zuhaili, Al-Fiqhu Al-Islami. 872-874. mudharabah tetap berlaku karena ia memiliki kecakapan (abliyab);

5. Harta mudharabah rusak di tangan mudharib. Apabila modal rusak atau hilang ditangan mudharib sebelum ia membeli sesuatu, maka mudharabah menjadi batal. Hal tersebut dikarenakan sudah jelas modal telah diterima oleh mudharib untuk kepentingan akad mudharabah. Demikian pula halnya, mudharabah dianggap batal apabila modal diberikan kepada orang lain atau dihabiskan sehingga tidak ada sedikit pun untuk dibelanjakan.

\section{KEDUDUKAN AGUNAN DALAM AKAD PEMBIAYAAN MUDHARABAH PADA BANK SYARIAH}

Ide untuk menggunakan bank dengan sistem bagi hasil telah muncul sejak lama dan ditandai dengan munculnya para pemikir Islam yang menulis mengenai bank syariah. Para pemikir Islam tersebut di antaranya Anwar Quraeshi (1946), Naiem Siddiqi (1948) dan Mahmud Ahmad (1952), dan ditulis kembali secara terperinci oleh Mawdudi (1961), selain itu tulisan-tulisan Muhammad Hamidullah pada tahun 1944-1962 bisa dikatakan sebagai pendahulu mengenai perbankan syariah. ${ }^{25}$

Perkembangan bank syariah modern tercatat di Pakistan dan Malaysia sekitar tahun 1940, yang ada pada waktu itu adalah usaha pengelolaan dana jamaah haji secara nonkonvensional. Pada tahun 1940 di Mesir didirikan Mit Ghamr Local Saving Bank oleh Ahmad El-Najar yang dibantu oleh Raja Faisal dari Arab Saudi. Gagasan lain muncul dari konferensi negara-negara Islam sedunia di Kuala Lumpur pada tanggal 21-27 April 1969 yang diikuti oleh 19 negara peserta. ${ }^{26}$

Gagasan mengenai bank syariah di Indonesia sendiri sudah dimulai pada pertengahan tahun 1970 yang dibicarakan pada seminar Indonesia-Timur Tengah pada tahun

\footnotetext{
${ }^{25}$ Muhamad, Pengantar..., 156.
}

${ }^{26}$ Ibid. 156 
1974 dan Seminar Internasional pada tahun 1976. Bank syariah pertama di Indonesia adalah Bank Muamalat yang merupakan hasil kerja tim Perbankan MUI yang ditandatangani pada tanggal 1 November $1991 .^{27}$

Munculnya bank syariah di Indonesia dalam perjalanannya ternyata mampu meningkatkan pangsa pasar, diversifikasi produk dan sumber daya manusia. Hingga saat ini bank syariah terus mengalami perkembangan yang cukup baik, karena bank syariah mampu menopang ekonomi keummatan dan sebagian besar masyarakat sudah mulai beralih ke perbankan syariah ini.

Sejak disahkannya Undang-Undang Nomor 10 Tahun 1998 tentang Perbankan yang merupakan perubahan atas UndangUndang Nomor 7 Tahun 1992 tentang Perbankan, industri perbankan di Indonesia terbagi menjadi bank yang melaksanakan kegiatan usaha secara konvensional (bank konvensional) dan bank yang melaksanakan kegiatan usaha berdasarkan prinsip syariah (bank syariah). Kemudian dalam UndangUndang Perbankan yang baru juga memungkinkan bank konvensional untuk membuka cabang syariah di bawah pengelolaan unit usaha syariah (UUS) di bank yang bersangkutan.

Menurut Pasal 1 Ayat (7) UndangUndang Nomor 21 Tahun 2008 tentang Perbankan Syariah menjelaskan, bank syariah adalah bank yang menjalankan kegiatan usahanya berdasarkan prinsip syariah dan menurut jenisnya terdiri atas Bank Umum Syariah dan Bank Pembiayaan Rakyat Syariah. ${ }^{28}$

Suatu transaksi sesuai dengan prinsip syariah apabila memenuhi unsur-unsur berikut ini: $^{29}$

\footnotetext{
27 Muhamad, Pengantar..., 156.

28 Undang Nomor 21 Tahun 2008 tentang Perbankan Syariah.

${ }^{29}$ Muhamad, Pengantar..., 160.
}

1. Transaksi tidak mengandung unsur kezaliman;

2. Bukan riba;

3. Tidak membahayakan pihak sendiri atau pihak lain;

4. Tidak ada unsur penipuan (gharar);

5. Tidak mengandung materi-materi yang diharamkan;

6. Tidak mengandung unsur judi (maisyir).

Dengan demikian, setiap produk yang dihasilkan oleh bank syariah haruslah berjalan dengan mempedomani konsep syariah, yaitu beroperasi atas dasar konsep bagi hasil dan tidak menggunakan bunga sebagai alat untuk memeperoleh pendapatan maupun membebankan bunga atas penggunaan dana dan pinjaman karena bunga merupakan riba yang diharamkan.

Salah satu diantara berbagai macam produk yang dikenalkan oleh bank syariah kepada masyarakat luas yang menggunakan jasa perbankan syariah dalam produk financing (pembiayaan atau penyaluran dana) ialah pembiayaan bagi hasil dengan menggunakan akad mudharabah.

Akad mudharabah merupakan suatu kegiatan investasi atau transaksi pembiayaan yang berdasarkan kepercayaan dari masingmasing pihak. Kepercayaan adalah unsur paling penting yang harus dijaga dalam akad mudharabah, yakni kepercayaan (amanah) dari pemilik modal (shabib al-maal) kepada pengelola (mudharib). Keuntungan yang diperoleh dari usaha tersebut dibagi di antara pemilik modal (shabib al-maal) dan pengelola dana (mudharib) berdasarkan nisbah yang telah disepakati oleh masing-masing pihak diawal akadnya. Kemudian apabila terjadi kerugian dari usaha itu, maka akan ditanggung sepenuhnya oleh pemilik modal (shabib almaal), kecuali jika pengelola dana (mudharib) melakukan kesalahan yang disengaja, lalai atau menyalahi perjanjian yang telah disepakati para pihak. Seandainya kerugian itu diakibatkan karena kecurangan atau kelalaian si pengelola, 
maka si pengelola harus bertanggung jawab atas kerugian tersebut. ${ }^{30}$

Akad mudharabah ini sangat menuntut tingkat kejujuran yang tinggi dan menjunjung keadilan serta kepercayaan antara kedua belah pihak, karenanya masing-masing pihak harus menjaga kepentingan bersama.

Sebagaimana dijelaskan dalam Pasal 210 ayat (2) Kompilasi Hukum Ekonomi Syariah (KHES) bahwa "Kerugian yang diakibatkan oleh meninggalnya mudharib, dibebankan pada pemilik modal."

Secara singkat skema mudharabah, yaitu pihak mudharib mengajukan permohonan kepada bank syariah (shabib al-maal), sehingga kedua belah pihak memiliki keinginan untuk melakukan sebuah aktifitas ekonomi (poyek/usaha), dimana mudharib memiliki keahlian/keterampilan dalam melakukan atau mengelola usaha tersebut, sedangkan bank syariah memiliki sumber dana (modal) untuk mendanai suatu poyek/usaha tersebut. Kemudian kedua belah pihak memiliki keinginan serta tujuan yang sama dalam melaksanakan sebuah aktifitas ekonomi (proyek/usaha) yaitu keuntungan, dari keuntungan tersebut akan dilakukan sebuah pembagian hasil berdasarkan keuntungan usahanya. Sehingga menimbulkan sebuah kesepakatan bersama yang dituangkan dalam sebuah kontrak, maka perjanjian tersebut merupakan perjanjian bagi hasil (mudharabab).

Pada Pasal 1 Ayat (26) UndangUndang Nomor 21 Tahun 2008 tentang Perbankan Syariah menyebutkan, bahwa agunan adalah jaminan tambahan, baik berupa benda bergerak maupun benda tidak bergerak yang diserahkan oleh pemilik agunan kepada Bank Syariah dan/atau UUS, guna menjamin pelunasan kewajiban nasabah penerimah fasilitas. $^{31}$

${ }^{30}$ Muhamad, Manajemen..., 239.

31 Undang Nomor 21 Tahun 2008 tentang Perbankan Syariah.
Pengaturan tentang agunan dalam transaksi mudharabah terdapat dalam Fatwa Dewan Syariah Nasional Nomor: 07/DSNMUI/IV/2000 tentang Pembiayaan Mudharabah yang menyatakan bahwa pada prinsipnya, dalam pembiayaan mudharabah tidak ada jaminan, namun agar mudharib tidak melakukan penyimpangan Lembaga Keuangan Syariah dapat meminta jaminan dari mudharib atau pihak ketiga.

Berdasarkan penjelasan dari fatwa DSN-MUI tersebut bahwa pada hakikatnya dalam akad pembiayaan mudharabah tidak diwajibkan adanya agunan dari bank syariah kepada nasabah. Pada dasarnya akad mudharabah ini adalah bersifat amanah, karena mudharib pada hakikatnya menjadi wakil dari pemilik modal dalam mengelolah dana.

Kemudian pada Pasal 6 huruf $(\mathrm{O})$ Peraturan Bank Indonesia Nomor: 7/46/PBI/2005 tentang Akad Penghimpunan dan Penyaluran Dana Bagi Bank Yang Melaksanakan Kegiatan Usaha Berdasarkan Prinsip Syariah juga mengatur bahwa bank dapat meminta agunan atau jaminan, tetapi Pasal 6 huruf (O) Peraturan Bank Indonesia Nomor: 7/46/PBI/2005 telah dicabut dan diganti dengan Peraturan Bank Indonesia Nomor: 9/19/PBI/2007 serta menghapus pasal yang membolehkan bank syariah meminta jaminan.

Sedangkan Fuqaha' menyatakan bahwa pada prinsipnya dalam akad mudharabah ataupun akad syirkah lainnya tidak perlu bahkan tidak boleh memintakan agunan atau jaminan dalam akad tersebut. ${ }^{32}$

Seperti praktiknya sekarang ini, mudharabah banyak mengalami perubahan sosial dan perkembangan (modifikasi), ini disebabkan karena adanya perubahan sosial dan perkembangan zaman. Sebagaimana Ibnu Qayyim al-Jauziyah merumuskan sebuah

32 Wahbah Zuhaili, Al-Fighu Al-Islami waAdilatubu, Jilid 5 (Damaskus: Al Mathba'ah alIslamiyah, 1969). 195. 
kaidah yang berbunyi: "Taghayyuru al-fatwa wa ikhtilaafubaa bihasbi taghayyuri al-azminati wa alamkinati wa al-abwaali wa an-nayaati wa al-'awaaidi", yang artinya adalah berubah dan berbedanya fatwa sesuai dengan perubahan tempat, zaman, kondisi sosial, niat dan adat kebiasaan. ${ }^{33}$

Pada dasarnya akad pembiayaan mudharabah bukan merupakan suatu perjanjian pinjam-meminjam dan bukan pula perjanjian utang-piutang antara kreditur dengan debitur melainkan perjanjian kerjasama (kemitraan) mengenai usaha bersama antara para pihak yang melakukan perjanjian bagi hasil dan keuntungan, yaitu antara bank sebagai pemilik modal (shabib al-maal) dengan nasabah sebagai pengelola usaha (mudharib). Jadi, apabila ternyata dalam perjanjian tersebut mengalami kegagalan ataupun kerugian, maka bank (shabib al-maal) akan menanggung semua risiko finansial atas terjadinya kerugian, sedangkan mudharib akan memikul risiko pikiran, tenaga, waktu dan kesempatan memperoleh imbalan finansial.

Fungsi agunan dalam akad mudharabah pada perbankan syariah adalah untuk menjamin pelaksanaan akad mudharabah sesuai dengan kesepakatan yang dibuat oleh para pihak diawal perjanjian, yakni antara pemilik modal (shahib al-maal) dengan pengelola (mudharib). Sedangkan fungsi agunan pada perbankan yang menjalankan kegiatan usaha secara konvensional adalah sebagai penjamin atas utang-piutang yang terjadi antara kreditur dengan debitur.

Jadi, sangatlah berbeda antara fungsi agunan pada perbankan syariah dengan perbankan konvensional. Akad mudharabah ini sangat mengedepankan kepercayaan (amanah) antara masing-masing pihak dengan menjunjung keadilan serta menuntut kejujuran yang tinggi demi menjaga kepentingan bersama. Oleh karena itu, apabila terjadi

${ }^{33}$ Ibnu Qoyyim al-Jauziyyah, I'lamal-Muwaqqi'in 'an Rabb al-Alamin, Jilid III, (Beirut: Dar al-Jail, 1975). 4. kerugian yang mana hal tersebut murni bukan disebabkan karena kelalaian, kesalahan yang disengaja dan pelanggaran perjanjian oleh mudharib, maka agunan yang ada tersebut tidak dapat disita.

Maka, tujuan agunan dalam akad mudharabah adalah untuk menghindari atau memperkecil risiko-risiko yang merugikan bank syariah akibat kelalaian, salah urus atau pelanggaran akad yang dilakukan oleh nasabah selaku pengelola (mudharib), serta untuk mencegah moral jelek dari pihak pengelola dana (mudharib) dan bukanlah untuk mengembalikan nilai investasi jika terjadi kerugian karena faktor risiko bisnis. ${ }^{34}$

Akan tetapi, untuk menghindari adanya moral jelek dari pihak pengelola dana (mudharib) atau menyalahi isi kontrak yang telah disepakati diawal, maka bank syariah sebagai pemilik modal (shabib al-maal) dibolehkan meminta agunan tertentu kepada nasabah (mudharib), tetapi bukanlah bersifat wajib atau suatu keharusan yang wajib dijalankan oleh bank syariah tersebut.

Pembiayaan dengan menggunakan akad mudharabah merupakan instrumen keuangan yang sangat strategis dalam rangka meningkatkan taraf hidup rakyat banyak dan sistem bagi hasil ini cocok dengan tradisi masyarakat kita, di samping memperluas penyediaan lapangan kerja, memberikan kontribusi yang signifikan terhadap pertumbuhan ekonomi dan bisa meratakan peningkatan pendapatan yang didasarkan pada prestasi. Pihak pengelola (mudharib) bekerja mengelola modal, sedangkan pihak pemilik modal (shahib al-maal) mempertaruhkan keberaniannya mengambil risiko atas kegiatan usaha yang disepakatinya dengan pihak pengelola (mudharib). Maka, atas risiko itulah pihak pemilik modal (shahib al-maal) berhak mendapatkan keuntungan berupa bagi hasil dari usaha yang dijalankan (mudharib) 
berdasarkan nisbah yang mereka sepakati dalam kontrak.

Dengan peran yang demikian, maka mudharabah sebagai salah satu instrumen keuangan harus dioptimalkan penerapannya, baik secara individu maupun di lembaga keuangan syariah. Hal ini dapat dilakukan melalui pendidikan dan sosialisasi kepada masyarakat, di samping penyempurnaan regulasi yang terus menerus dilakukan oleh pemerintah maupun peran serta dari pihak terkait lainnya.

Sebagaimana halnya bank konvensional, sebagai lembaga perbankan, bank syariah juga terikat untuk melaksanakan prinsip kehati-hatian dalam menjalankan kegiatan usahanya, berdasarkan ketentuan dalam Pasal 35 Ayat (1) Undang-Undang Nomor 21 Tahun 2008 tentang Perbankan Syariah (UUPS), agar bank syariah selalu dalam keadaan sehat serta terjaga likuiditas dan solvabilitasnya. Selanjutnya, dijelaskan dalam Pasal 36 Undang-Undang Nomor 21 Tahun 2008 tentang Perbankan Syariah, bahwa bank syariah dalam menyalurkan pembiayaan dan melakukan kegiatan usaha lainnya wajib menempuh cara-cara yang tidak merugikan bank syariah, dan/atau unit usaha syariah dan kepentingan nasabah yang mempercayakan dananya. Jadi, pada dasarnya prinsip kehatihatian tersebut adalah sebagai jaminan kepatuhan bank syariah terhadap semua ketentuan dan peraturan yang berlaku. ${ }^{35}$

\section{KESIMPULAN}

Akad mudharabah merupakan suatu kontrak kerjasama antara dua pihak dimana satu pihak sebagai pemilik modal (shabib almaal) mempercayakan modal/uangnya kepada pihak kedua sebagai pengelola (mudharib) untuk tujuan menjalankan suatu usaha perdagangan dan keuntungannya dibagi berdasarkan nisbah

35 Danang Wahyu Muhammad, "Kajian tentang Pembiayaan Mudharabah pada Bank Syariah," Jurnal Media Hukum (Desember, 2011). 233. yang mereka sepakati dalam kontrak, sedangkan pihak pengelola (mudharib) menyumbangkan tenaga, waktunya dan mengelola perkongsian mereka tersebut berdasarkan proporsi yang telah disepakati sebelumnya. Adapun kerugian dan risiko yang muncul dalam akad mudharabah akan ditanggung sendiri oleh si investor atau pemilik modal (shabib al-maal), kecuali kerugian tersebut disebabkan oleh kesalahan yang disengaja, kelalaian dan pelanggaran kesepakatan oleh pihak pengelola (mudharib). Seandainya kerugian itu diakibatkan karena kecurangan atau kelalaian si pengelola, maka si pengelola harus bertanggung jawab atas kerugian tersebut.

Kedudukan agunan pada akad mudharabah di perbankan syariah berbeda dengan kedudukan agunan pada perbankan konvensional, agunan pada perbankan konvensional berfungsi sebagai penjamin atas utang-piutang yang terjadi antara kreditur dengan debitur. Sedangkan fungsi agunan dalam akad mudharabah pada perbankan syariah adalah untuk menjamin terlaksananya akad mudharabah sesuai dengan kesepakatan yang telah dibuat diawal perjanjian antara pemilik modal (shabib al-maal) dengan pihak pengelola (mudharib). Tujuan agunan dalam akad mudharabah adalah untuk menghindari atau memperkecil risiko-risiko yang merugikan bank syariah akibat kelalaian, salah urus atau pelanggaran akad yang dilakukan oleh nasabah selaku pengelola (mudharib), serta untuk mencegah moral jelek dari pihak pengelola dana (mudharib) dan bukanlah untuk mengembalikan nilai investasi jika terjadi kerugian karena faktor risiko bisnis. Akad mudharabah ini sangat mengedepankan kepercayaan (amanab) antara masing-masing pihak dengan menjunjung keadilan serta menuntut kejujuran yang tinggi demi menjaga kepentingan bersama. 


\section{DAFTAR KEPUSTAKAAN}

Antonio, Syafi'i. Bank Syariah Wacana Ulama dan Cendikiawan. Jakarta: Tazkia Institute, 1999.

Dahlan, Abdul Azis. Ensiklopedi Hukum Islam. Jakarta: PT. Iktiar Baru Van Hoeve, 2003.

Emzir.Metodologi Penelitian Kualitatif: Analisis Data. Jakarta: Penerbit Rajawali Pers, 2010.

Imaniyati, Neni Sri. Aspek-Aspek Hukum BMT. Bandung: PT Citra Aditya Bakti, 2010.

Karim, Adiwarman A. Bank Islam: Analisis Fiqih dan Keuangan. Jakarta: PT Raja Grafindo, 2004.

Al-Kasani, 'Alaudin. Badaai' Ash-Shanai' fi Tartib Asy-Syarai', Juz 6. Beirut: Dar Al-Fikr, 1996.

Muhammad. Konstruksi Mudharabah dalam Bisnis Syariah: Mudharabah dalam Wacana Fiqih dan Praktik Ekonomi Modern. Yogyakarta: BPFE Yogyakarta, 2005.

Muhamad. Lembaga-Lembaga Kenangan Umat Kontemporer. Yogyakarta: UII Press Yogyakarta, 2000.

Muhamad. Manajemen Kenangan Syariah. Yogyakarta: UPP STIM YKPN, 2014.

Muhamad. Pengantar Bisnis Syariah. Yogyakarta: UPP STIM YKPN, 2019.

Muslich, Ahmad Wardi. Fiqh Muamalat. Jakarta: Amzah, 2013.

Nafan. Pembiayaan Musyarakah dan Mudharabah. Yogyakarta: Graha Ilmu, 2014.

Rusyd, Ibnu. Bidayah al-Mujathid. Mesir: Dar Al-Fkir, t.t.

Sabiq, Sayid. Fiqh As-Sunnah, Juz 3. Beirut: Dar Al-Fikr, 1981.

Saeed, Abdullah. Menyoal Bank Syariah: Kritik Atas Interpretasi Bunga Bank Kaum Neo-Revivalis. Jakarta: Paramadina, 2004.

Soekanto, Soejono dan Sri Mamudji.Penelitian Hukum Normatif: Suatu Tinjauan Singkat. Jakarta: Rajawali Pers, 2001.

Sudarsono, Heri. Bank dan Lembaga Kenangan Syariab Deskripsi dan Ilustrasi. Yogyakarta: Ekonosia, 2004.

Zuhaili, Wahbah. Al-Fiqhu Al-Islami wa-Adilatubu, jilid 5. Damaskus: Al Mathba'ah al-Islamiyah, 1969.

Artikel Jurnal:

Muhammad, Danang Wahyu. Kajian tentang Pembiayaan Mudharabah pada Bank Syariah.Jurnal Media Hukum. 2011.

Musjtari, Dewi Nurul. Rekonstruksi Lembaga Penyelesaian Sengketa Akad Pembiayaan Dengan Jaminan Hak Tanggungan Pasca Putusan Mahkamah Konstitusi Nomor 93/PUU-X/2012. Jurnal Media Hukum. Volume ke-23, Nomor 1: 2016.

\section{Peraturan Perundang-Undangan:}

Undang-Undang Nomor 21 Tahun 2008 tentang Perbankan Syariah.

Undang-Undang Nomor 10 Tahun 1998 tentang Perbankan.

Undang-Undang Nomor 3 Tahun 2004 tentang Bank Indonesia.

Fatwa Dewan Syariah Nasional Nomor 07/DSN/MUI/IV/2000 tentang Pembiayaan Mudharabah.

Peraturan Bank Indonesia Nomor: 9/19/PBI/2007 tentang Pelaksanaan Prinsip Syariah dalam Kegiatan Penghimpunan Dana dan Penyaluran Dana Serta Pelayanan Jasa Bank Syariah.

Kompilasi Hukum Ekonomi Syariah (KHES). 